\title{
Democracy's Muse: How Thomas Jefferson Became an FDR Liberal, a Reagan Republican, and a Tea Party Fanatic, all the while being Dead
}

Review Number: 1850

Publish date: Thursday, 29 October, 2015

Author: Andrew Burstein

ISBN: 9780813937229

Date of Publication: 2015

Price: $£ 26.50$

Pages: 272pp.

Publisher: University of Virginia Press

Publisher url: http://books.upress.virginia.edu/detail\%2Fbooks\%2Fgroup4827.xml?q=Democracy\%E2\%80\%99s\%20Muse

Place of Publication: Charlottesville, VA

Reviewer: David W. Houpt

In one of his last letters to his neighbor and confidant, Thomas Jefferson asked James Madison 'to take care of me when dead'.(1) Jefferson, like most of the 'founding fathers' thought deeply about his legacy and place in history. He spent hours arranging his papers for posterity and composed a memoir of sorts, the 'Anas', in an effort to set the record straight. He had good reason to worry.

Jefferson's reputation has experienced more ups and downs than perhaps that of any other figure in American history. He has been celebrated by the left as a great philosopher of democracy and defender of the common man, and has been lauded by the right for his belief in states' rights and opposition to 'big government'. He has been seen as a symbol of equality and tarred as a racist and proto-eugenicist. The past 20 years in particular have not been kind to Jefferson. Overshadowed by figures like John Adams (who David McCullough managed to rescue from near-obscurity) and Alexander Hamilton (who recently made it to Broadway), what recognition Jefferson has received lately has been negative. Although his figure still graces our currency, appears in stone at Mt. Rushmore, and stands tall on the tidal basin at the Nation Mall, Jefferson is now remembered more for what he did in the bedroom than what he did as a public servant.

The twists and turns of Jefferson's legacy is the subject of Andrew Burstein's new book Democracy's Muse: How Thomas Jefferson Became an FDR Liberal, a Reagan Republican, and a Tea Party Fanatic, All While Being Dead. The book is divided into two sections: the first charts the ways in which politicians have used (and abused) Jefferson from 1943 to 2012, and the second explores how Jefferson has factored into recent 'Culture Wars.' Democracy's Muse is not without its flaws but, on a whole, it is both an interesting and relevant analysis of the politics of historical memory.

Burstein begins his study of Jefferson's image with FDR and the dedication of the Jefferson Memorial. According to Burstein, Jefferson's popularity among liberals peaked during FDR's presidency. In the Age of Roosevelt, Jefferson was a liberal humanist and democracy's guiding light. He was a partisan figure, just as 
he had been in his lifetime. Although this Jefferson 'was not wholly Democratic, it was, most assuredly, Democrats who 'owned' him' (p. 7) Burstein contends that this version of Jefferson originated from Claude G. Bowers's book Jefferson and Hamilton: The Struggle for Democracy in America. A 'dyed-in-the-wool Democrat', Bowers portrayed the battles between Jefferson and Hamilton as a fight between the forces of good and evil (pp. 4-5). On one side stood Jefferson, who supported equal opportunities for all men regardless of background or status. On the other was Hamilton, who favored the rich, despised the common man and sought to undermine American democracy.

FDR saw parallels between the Jefferson/Hamilton debate and the contemporary struggles between New Deal Democrats and Republicans. Democrats, like Jefferson, fought against private greed and corruption while Republicans, like Hamilton, supported banks and opposed regulations against monopolies and other government efforts to level the playing field. FDR, with Bowers's help, succeeded to remaking Jefferson in the public imagination, but there were signs of future trouble. By the end of the Second World War, Jefferson had acquired a reputation as being a 'comparatively 'slippery' figure' (p. 23).

The presidents immediately following FDR did not refer much to Jefferson. Democrats continued to revere (and claim) Jefferson while books including Nathan Schachner's Thomas Jefferson 'kept the eminently quotable New Deal humanist Jefferson alive' (p. 28). Only in 1960, with the election of JFK, did Jefferson return to center stage. Kennedy was a devoted student of Jefferson and spoke about the third president frequently. His most famous reference to Jefferson came during a White House dinner with Nobel Prize winners. Supposedly ad-libbed, Kennedy addressed the crowd by stating that it was 'the most extraordinary collection of talent, of human knowledge ... ever gathered at the White House, with the possible exception of when Thomas Jefferson dined alone' (p. 45). Kennedy looked up to and compared himself to the third president just as FDR had. Both Presidents believed they were continuing Jefferson's fight for greater equality and liberty. The historian Arthur Schlesinger helped make the connection between Jefferson and Kennedy more explicit and argued that ' $[t]$ he line from Jefferson to Roosevelt to Kennedy was fairly direct' (p. 37).

Despite Kennedy's embrace, the Jefferson of the 1960s was no longer irreproachable. In 1963 Leonard Levy's Jefferson and Civil Liberties: The Darker Side struck at the image of Jefferson as the defender of liberty. According to Levy, Jefferson frequently compromised people's liberties and rights when he felt justified, most notably during the Aaron Burr Treason trial. Although 'Levy's criticism never quite got through,' it foreshadowed future troubles (p. 53).

Jefferson entered the 1970s on shaky ground. For the most part, he lacked a public defender. LBJ, Nixon and Ford rarely mentioned Jefferson. The most influential portrayal of Jefferson came from UCLA historian Fawn Brodie. Her Thomas Jefferson: An Intimate History, published in 1974, sought to humanize the third president; the most significant contribution was the (re)discovery of Jefferson's relationship with Sally Hemings. Although rumors had circled that Jefferson had been intimate with one of his slaves during his lifetime, historians had mostly viewed these accusations as forms of character assassination. Jefferson, the standard narrative went, had been left heartbroken at 39 when his wife Patty died, and he kept his promise never to remarry (and therefore to remain celibate). Brodie, however, argued that Jefferson and Hemings (his wife's half-sister) fell in love and that the two had a decades-long relationship. Although Brodie's book met with commercial success, Burstein notes that uncovering the affair did not immediately damage Jefferson's reputation. The Jefferson two-dollar bill was introduced in 1976 and, as part of the fanfare surrounding the bicentennial, multiple cities and communities celebrated 13 April 1976 (his birthday) as Jefferson Day.

The conservative tidal wave that swept Ronald Reagan into the White House, however, completely washed away the liberal-humanist veneer FDR and JFK had applied to Jefferson. In Reagan's mind, Jefferson stood for small government, individualism and, above all else, personal freedom. Just as FDR had, Reagan relied heavily on Jefferson's image and legacy. For example, Jefferson was at the centerpiece of one of Reagan's most important speeches. Speaking at the Jefferson Memorial in 1987, Reagan proclaimed that: 
'It's time to finish the job Jefferson began and to protect our people and their livelihoods with restrictions on government that will ensure the fundamental economic freedom of the people the equivalent of an Economic Bill of Rights. I'm certain if Thomas Jefferson were here, he'd be one of the most articulate and aggressive champions of this cause' (p. 77).

Reagan, Burstein concludes, 'returned Jefferson to the inflexible Old Republican that the Virginian was in his own time, the guardian of unobtrusive government' (p. 78).

In the last chapter of the first section, Burstein covers Jefferson since William Jefferson Clinton. As Jefferson's namesake, Clinton did what he could to return Jefferson to the Democratic fold, but Burstein finds that 'Jefferson belonged most to Republicans in the 1990s' (p. 90). Like Clinton, however, Jefferson's image spent much of the decade struggling to get past the intimate details of his sex life. A DNA study conducted in the late 1990s proved that Jefferson (or one his close relatives) fathered children with Hemings. The evidence, which pundits likened to the discovery of Clinton's DNA on Monica Lewinsky's dress, provided fodder for critics of Jefferson. 'As the century's final decade wound down', Burstein finds, 'revisionists both popular and scholarly converted the admittedly paradoxical Jefferson - slaveholding freedom-lover, freethinker who found sublimity in the morals of Jesus - into a psychically damaged, coldblooded, and occasionally predatory renegade' (p. 100).

Thus far, Burstein contends, the 21st-century Thomas Jefferson has been most associated with the Tea Party. This Jefferson 'belongs to the vernacular, and to a new-fashioned political moralism that combines a belief in exceptionalism with a belief in the power of self-expression, even if that self-expression is disconnected from either social responsibility or actual historical experience' (p. 120). Often armed with fake quotations, members of the far right wing including Glenn Beck and Newt Gingrich have seized Jefferson, along with the entire founding generation, as exemplars of American greatness. The liberal-humanist Jefferson, Burstein finds, is a relic of the 20th century.

The second half of Democracy's Muse is dedicated to exploring how Jefferson, both as a historical figure and a symbol, has factored into recent 'culture wars'. The first chapter in this section, titled "'Misery enough, but no poetry": race and the remaking of a symbol' is the most relevant given the state of race relations in the nation. Burstein makes no attempt to hide the fact that Jefferson owned slaves and looked down on people with color. But he sees it as 'too simple, and simply wrong, to mark Jefferson as a monster' (p. 127). Burstein argues that we should understand Jefferson as both a human who, like all humans, has flaws and is product of his/her time. However, not everyone has been willing to accept this image of Jefferson as a man with defects.

Despite the mounting evidence, in 1998 an outspoken group of (white) descendants of Jefferson formed the Thomas Jefferson Heritage Society in an effort to prove that Thomas Jefferson was 'innocent' of the charges that he slept with his slave. By this point even the Monticello Association, which had fought to prevent any black descendants from being allowed to be buried in the family graveyard, had accepted the reality of the situation. Burstein draws parallels between the views of the Heritage Society and the split between contemporary Democrats and Republicans. Like the Heritage Society, conservatives view anything that threatens the 'great man historical narrative' as an assault on their way of life. More broadly, Burstein argues that the differences in the way Jefferson is viewed and used as a political figure reflects the fact that liberals have accepted a racially pluralistic society and conservatives have not. This is partly what makes the Revolutionary Era so appealing to conservatives - it was a time when blacks were monitored and controlled by whites. While a post-racial society has remained elusive, Burstein finds that progress has been made and events including a 2012 exhibit on slavery at Monticello at the National Museum of American History means that the real Jefferson is coming 'into clearer focus' (p. 159).

In a section on Jefferson and religion, Burstein points out that the third president's religion, or lack thereof, 
was a frequent topic of conversation during his lifetime. He was attacked for being a deist, if not atheist. Currently, however, the religious right has attempted to remake Jefferson into a model Christian. This makeover, Burstein believes, would be anathema to Jefferson. Although the third president did produce his own version of the Bible, the purpose of the exercise had been to remove the supernatural. Nevertheless, Reagan, Gingrich and evangelical Christian conservative David Barton have all gone to great effort to show that Jefferson was a good Christian. What explains this seemingly quixotic campaign to baptize Jefferson? Burstein argues that it is part of the religious right's effort to remake America into a Christian nation. Jefferson had to be a Christian, in this view, because the Declaration of Independence, like the Constitution, was divinely inspired.

Despite their best efforts, making a Christian out of Jefferson turned out to be too difficult a task. David Barton's The Jefferson Lies, which made the case for the pious Jefferson, was so discredited that it was eventually pulled from bookshelves. Unable to make a Christian out of Jefferson, the religious right moved to cut Jefferson out of history. In what Burstein describes as the 'low point in Jefferson's posthumous career as a patriotic symbol' the Texas Board of Education, which exerted significant influence over the textbook industry nationwide, concluded that Jefferson's historical role should be minimized while Reagan should receive more attention (p. 179). If they could not make a Christian out of him, they could at least try and erase him from memory.

The final chapter considers the politics of history and memory more broadly. Like just about everything in America today, the fault-lines in this debate are the same as those that split Democrats from Republicans. Liberals, according to Burstein, see history as 'a cautionary tale justifying the need for creative change'. In contrast, '[f]or conservatives, it is a cautionary tale justifying the need to monitor change lest it diminish the inherited values of a hallowed past' (p. 197). Jefferson, it would seem, can be used to fit both interpretations. Those on the left turn to Jefferson as a symbol of participatory democracy and the power of reason while the right considers him a staunch defender of states' rights and opponent of big government. Both sides, in effect, are right, just as they are both wrong. 'There are multiple Jeffersons,' Burstein concludes, 'because there is never one solitary history. We are unlikely to find a Jefferson we all like and keep his flame burning. But that's all right. We owe it to ourselves not to homogenize the first 'greatest generation'; nor should we ever hope to rescind the part of the past we dislike' (p. 210).

As Democracy's Muse clearly demonstrates, it is an American tradition to invoke the founding fathers as a means of justifying a political agenda. The irony of the focus on Jefferson and other luminaries is that they viewed history as a march towards greater reason and enlightenment. Posterity, Jefferson believed, would be more developed and advanced than the men of his time. While history has proven Jefferson right in some regards, there is something puzzling about looking to the 1790 s for guidance on what to do in the $21 \mathrm{st}$ century.

Democracy's Muse reminds readers of the power of historical memory and that the way current political beliefs color the view of the past. Burstein rightly asserts that historical context is everything and that '[i]n adopting a Jefferson for our time, we mock ourselves' (p. 196). It is, however, natural to look to the past for guidance and to question whether political figures we revere would approve of the America of today. This tendency only becomes problematic when politics cloud reason and reverence for the past replaces an appreciation for positive change.

While Democracy's Muse does an excellent job highlighting the malleability of memory, the book's structure and scope leave some important questions unexamined. The way a President uses Jefferson's memory relates to cultural norms, and by separating the two Burstein missed an opportunity to provide a more nuanced look at the politics of memory. The decision to open the book with FDR and the dedication of the Jefferson Memorial ignores the extent to which Jefferson was a symbol during his own lifetime. In the 1790s and 1800s Jefferson's supporters saw him as great defender of liberty and freedom while his opponents considered him a morally bankrupt demagogue. He remained a potent symbol throughout the 19th century as well. Burstein references slavery and touches on Abraham Lincoln's Jefferson but mostly 
overlooks the fact that by 1944 Americans had been fighting over Jefferson's legacy for more 150 years. It would have been helpful to learn about how past iterations of Jefferson relate to those being used today.

So what does the future for Jefferson hold? Burstein offers little in the way of predictions, other than noting that the Sage of Monticello appears firmly entrenched as a conservative. Considering the future of Jefferson's legacy does, however, leave one wondering: What is the role of the academic historian? How much influence do well-researched and carefully thought out analyses really have? Burstein points to a few examples where historians drove the public's perception of Jefferson but it also appears that larger forces are at work. Are the historians merely products of their environment? If so, what does it say about the profession as a whole? These are not new questions but, in light of the work he has done on this book, it would be particularly interesting to learn how Professor Burstein would respond to them.

In the end, whether Jefferson remains unpopular or he mounts a comeback, rejoins the Democratic Party or stays with the GOP, it is fair to conclude that we have not heard the last of him.

\section{Notes}

1. Thomas Jefferson to James Madison, 17 February 1826, 'Thomas Jefferson: Legacy' Library of Congress <http://www.loc.gov/exhibits/jefferson/215.html [2]> [accessed 9 August 2015].Back to (1)

\section{Other reviews:}

Slate

http://www.slate.com/articles/podcasts/gist/2015/04/the_gist_andrew_burstein_on_thomas_jefferson_and_debbie_w: [3]

Source URL:https://reviews.history.ac.uk/review/1850

\section{Links}

[1] https://reviews.history.ac.uk/item/142291 [2] http://www.loc.gov/exhibits/jefferson/215.html [3] http://www.slate.com/articles/podcasts/gist/2015/04/the_gist_andrew_burstein_on_thomas_jefferson_and_debbie_w 